\title{
PEMETAAN TOPIK NILAI PUBLIK DALAM PENELITIAN
}

\author{
Rika Wulandari ${ }^{1}$, Emma Rochima $^{2}$, Yan Rianto ${ }^{3}$, Cipta Endyana ${ }^{4}$ \\ 1,2,4 Program Magister Inovasi Regional Sekolah Pascasarjana Universitas Padjadjaran \\ 1,3 Pusat Pemanfaatan dan Inovasi IPTEK - LIPI \\ *Korespondensi: rika19008@ mail.unpad.ac.id
}

Diajukan: 03-09-2020; Direview: 12-09-2020; Diterima: 17-10-2020; Direvisi: 28-10-2020

\begin{abstract}
This study aims to provide an overview of how public value research topics developed from 2001 to 2020. The mapping is expected to provide an overview of the development of research and provide input on the topic of public value research. This study uses the Scopus database from 2001 to 2020 to calculate citation analysis using the Publish or Perish (PoP) application and mapping publications using the VOSViewer application. From the analysis of literature studies based on the Scopus database from 2001 to 2020272 journal articles are discussing public value research, it was found that the most publications were in 2019 (47 publications) and the highest research was dominated by the United Kingdom (65). For the highest number of citations, the publication with the title "From new public management to public value: Paradigmatic change and managerial implications" was 368 citations. Social science subjects are the most discussed in research on public values. The results of the visualization with the VOSViewer application for a public value research network visualization map are divided into 4 clusters. Density visualization maps can be seen that research on the topic of public value with the subject of performance management and cultural policy is still small, so there is still a chance for research. Based on the analysis of the research topic of public value, there is still a large enough opportunity for research to be carried out, especially in Indonesia based on the Scopus database, researchers have not researched the topic of public value research.
\end{abstract}

\begin{abstract}
ABSTRAK
Kajian ini bertujuan untuk memberikan gambaran bagaimana topik penelitian nilai publik berkembang dari tahun 2001 sampai 2020. Pemetaan tersebut diharapkan dapat memberikan gambaran sejauh mana perkembangan penelitian serta memberikan masukan mengenai topik penelitian nilai publik. Penelitian ini, menggunakan basis data Scopus dari tahun 2001 sampai 2020, untuk menghitung analisa sitasi menggunakan aplikasi Publish or Perish (PoP) serta pemetaan publikasi menggunakan aplikasi VOSViewer. Dari hasil analisis studi literatur berdasarkan basis data Scopus dari tahun 2001 sampai 2020 terdapat 272 artikel jurnal yang membahas penelitian nilai publik, ditemukan publikasi terbanyak ditahun 2019 (47 publikasi) dan penelitian tertinggi didominasi oleh United Kingdom (65). Untuk jumlah sitasi tertinggi yaitu publikasi dengan judul "From new public management to public value: Paradigmatic change and managerial implications" sebanyak 368 sitasi. Subjek ilmu sosial merupakan paling banyak di bahas dalam penelitian tentang nilai publik. Hasil visualisasi dengan aplikasi VOSViewer untuk peta visualisasi network penelitian nilai publik terbagi atas 4 klaster. Peta visualisasi density dapat terlihat penelitian dengan topik nilai publik dengan subjek performance management dan cultural policy masih sedikit sehingga masih berpeluang untuk dilakukan penelitian. Berdasarkan dari analisis topik penelitian nilai publik, masih berpeluang cukup besar untuk dilakukan penelitian, terutama di Indonesia berdasarkan basis data Scopus belum ada peneliti yang melakukan penelitian dengan topik penelitian nilai publik.
\end{abstract}

Keywords: Public value; Research; Scopus; Publish or perish; VOSviewer

\section{PENDAHULUAN}

Nilai publik dan konsep terkait seperti barang publik, kepentingan publik, dan ranah publik telah secara aktif diperdebatkan dalam filsafat politik sejak zaman Yunani Kuno (Benington \& Moore, 2011). Nilai dan konsep istilah nilai publik (public value) menarik pemikiran tentang pentingnya keterlibatan dalam dialog tentang nilai-nilai, konflik nilai, dan peran sektor publik dalam mengubah konteks pemikiran masyarakat. Namun, nilai publik dapat digambarkan seperti ayunan pada sebuah bandul yang teratur diikuti oleh harapan yang memuaskan atau kekecewaan dari keterlibatan karena kegagalan dalam mencapai tujuan (Meynhardt, 2009). Studi terkait nilai 
publik dimulai oleh Moore (1995) lebih fokus pada isu-isu manajemen dan nilai-nilai pegawai publik, yaitu membantu manajer publik untuk melayani publik atau masyarakat dengan lebih baik.

Di sisi lain, studi nilai publik lebih fokus dan lebih banyak mengidentifikasikan serta memberlakukan syarat yang memenuhi nilai-nilai dari nilai publik. Dalam penelitian yang dilakukan oleh Jørgensen \& Bozeman (2007); Nabatchi (2012); Jørgensen \& Rutgers (2015), nilai publik diidentifikasikan dengan tidak hanya meningkatkan kerja manajer publik tetapi juga sebagai isu agenda penting bagi politisi, warga negara, organisasi dan masyarakat. Moore (1995) mendefinisikan nilai publik menjadi empat gagasan, yaitu: (1) untuk mencapai tujuan yang diamanatkan, layanan harus bersifat efisien dan efektif; (2) layanan harus memiliki standar profesional sehingga dapat menetapkan tolok ukur untuk sektor publik; (3) nilai publik dapat diperoleh melalui teknik analitik seperti evaluasi program dan analisis efektivitas biaya; (4) nilai publik dapat diukur dengan kepuasan pengguna dan penyedia layanan. Sedangkan untuk merumuskan kembali pendekatan nilai publik ke dalam kerangka kerja harus dimulai dari analisis organisasi (Bromell, 2017).

Ketertarikan terhadap nilai-nilai publik telah meningkat dalam beberapa tahun terakhir. Mengingat pluralitas yang melekat dari public value dalam administrasi publik (Van Der Wal \& Van Hout, 2009; Harmon, 2011), para sarjana telah mengembangkan sistem klasifikasi untuk nilai publik (Jørgensen \& Bozeman, 2007), gagasan tentang menciptakan nilai publik (Moore, 1995) dan mencegah kegagalan nilai publik (Bozeman, 2007), dan ide-ide untuk merekonsiliasi konflik nilai publik (Spicer, 2009). Kajian penelitian tentang nilai publik saat ini banyak digunakan di bidang studi sosial science. Permasalahan inilah yang kemudian mendorong peneliti untuk melakukan penelitian dengan studi literatur tentang topik nilai publik. Penelitian ini menyajikan tinjauan literatur yang komprehensif tentang keadaan penelitian saat ini dengan subjek nilai publik serta untuk menemukan jalur penelitian baru. Penelitian ini bertujuan untuk memetakan ranah riset dengan topik nilai publik, memberikan gambaran untuk penelitian lebih lanjut terkait dengan topik nilai publik. Hasil penelitian ini diharapkan dapat menjadi bahan informasi serta rujukan untuk penelitian lebih lanjut.

\section{TINJAUAN PUSTAKA}

\subsection{Nilai Publik}

Nilai publik berarti ada kesepakatan normatif tentang: (a) hak, manfaat, dan hak prerogatif kepada warga negara; (b) kewajiban warga negara kepada masyarakat, negara, dan satu sama lain; (c) prinsip-prinsip yang menjadi dasar pemerintah dan kebijakan (Bozeman, 2007). Studi awal tentang nilai publik biasanya fokus pada nilai-nilai yang diidentifikasikan, ditanamkan, dan disadari oleh pegawai publik (Moore, 1995; Williams \& Shearer, 2011; Bryson, Crosby, \& Bloomberg, 2014) dan kemudian diperluas nilai-nilai publik yang mencakup nilai-nilai dari warga negara, organisasi, dan masyarakat serta nilai-nilai yang tertuang dalam kebijakan publik (Jørgensen \& Bozeman, 2007; Nabatchi, 2012).

Moore (1995) mendefinisikan nilai publik untuk menggambarkan empat gagasan yang lebih khusus dalam membantu pekerjaan manajerial disektor publik dan mendefinisikan serta mengukur nilai publik selama beberapa dekade terakhir, yaitu: (1) manajer harus mencapai tujuan yang diamanatkan dengan seefisien dan seefektif mungkin; (2) standar profesional dapat menetepkan tolok ukur untuk produksi sektor publik; (3) Nilai publik dapat diketahui melalui teknik analitik seperti evaluasi program, analisis efektivitas biaya; (4) Nilai publik dapat diukur dari kepuasan dan pengguna layanan. 


\subsection{VOSViewer}

VOSViewer adalah perangkat lunak freeware untuk membuat peta berdasarkan data yang kita pilih dan memvisualisasikan dalam bentuk peta (Naukkarinen \& Bragge, 2016). Menurut Van Eck \& Waltman (2009), VOSViewer dikembangkan untuk melihat peta bibliometrik. VOSViewer dapat menampilkan peta dengan berbagai macam cara, masing-masing menekankan aspek yang berbeda dari peta.

\subsection{Publish or Perish}

Publish or Perish (PoP) yaitu aplikasi yang freeware untuk menghitung analisa sitasi. Perangkat lunak ini dibuat oleh website professor yang bernama Anne-Will Harzing (Bensman, 2011).

\section{METODE}

Penelitian ini menggunakan metode tinjauan literatur. Metode yang mengadopsi secara tepat, transparan dan pendekatan eksplisit yang mencakup serangkaian fase untuk memastikan bahwa ketelitian dan transparansi ke proses tinjauan literatur (Tranfield et al., 2003). Metode tinjauan literatur ini dilakukan berdasarkan pada penelitian yang di lakukan oleh Setyaningsih (2019) dan Garza-Reyes (2015) dengan tahapan penelitian sebagai berikut (Gambar 1).

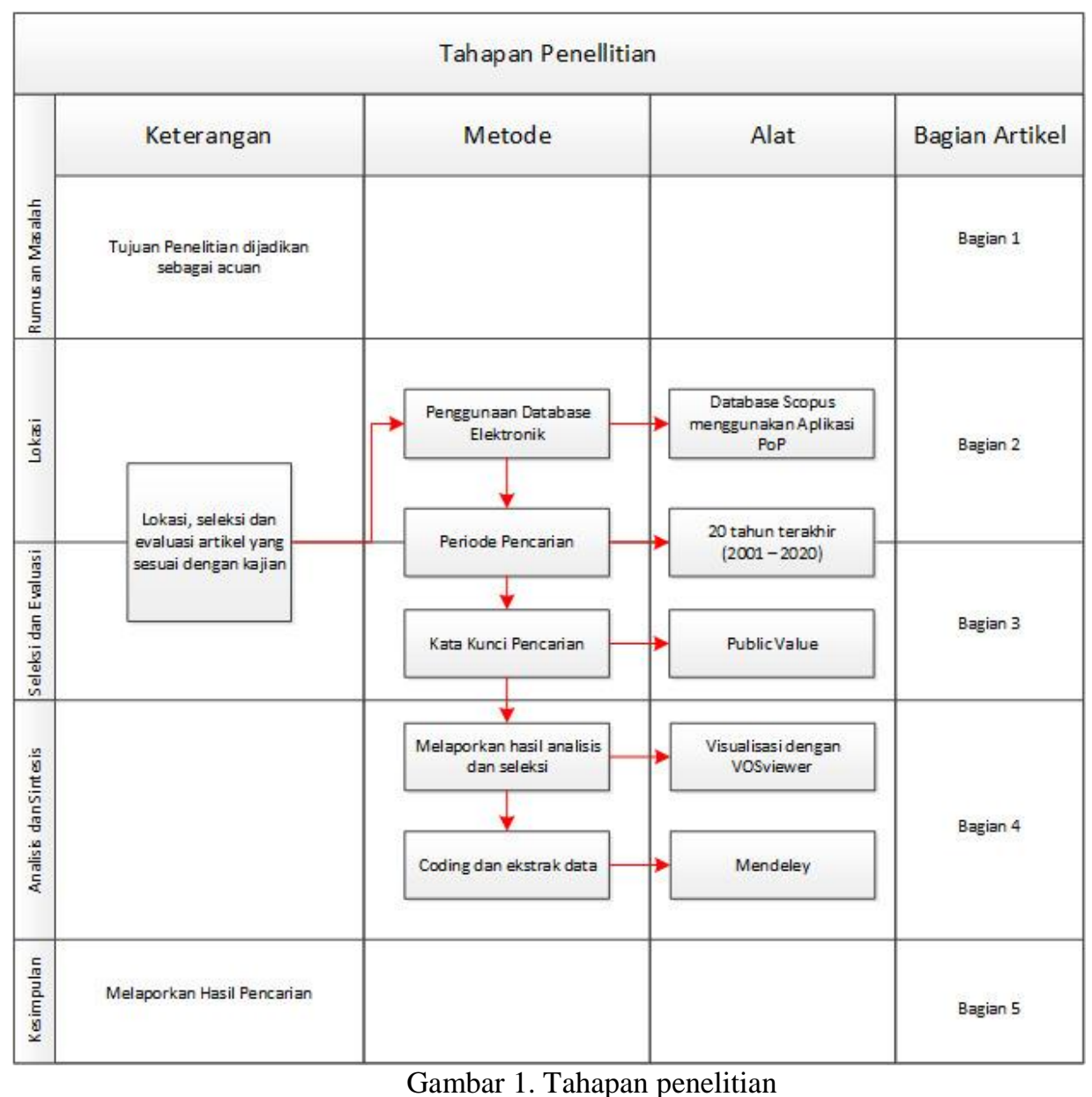

Sumber data berasal dari Scopus, dengan kurun waktu selama 20 (dua puluh) tahun terakhir (dari tahun 2001 - 2020), dengan dibatasi kata kunci "public value" dan jenis publikasi "jurnal". Hasil penelusuran dari Scopus kemudian di-export ke ektensi *.RIS dan dimasukkan ke dalam software PoP. Selain menggunakan VOSviewer untuk memetakan publikasi, penulis juga 
menggunakan software PoP. Kemudian, data dipetakan secara visual dengan VOSviewer. Hasil analisis kemudian disusun dalam bentuk tabulasi untuk keperluan pengamatan. Setelah diolah dan disusun berurutan kemudian disajikan dalam bentuk visualisasi peta dan grafik.

\section{HASIL DAN PEMBAHASAN}

\subsection{Analisis Publish or Perish}

Berdasarkan basis data Scopus dengan kata kunci "public value" dan jenis publikasi "jurnal" diperoleh 272 dokumen. Informasi berdasarkan Gambar 2, diperoleh hasil analisis PoP terhadap kajian "public value" dengan uraian sebagai berikut: tahun publikasi (publication years), merupakan tahun terbit jurnal yang tercantum dalam Scopus yaitu tahun 2002 - 2020 serta tahun 2001 belum ada penulis yang mengkaji topik penelitian "public value"; jumlah tahun sitasi (citation years) yaitu 18 tahun; dengan total artikel (papers) sebanyak 272 artikel; jumlah sitasi (citations) yaitu 5007; angka sitasi pertahun jurnal (cites/year) sebesar 278.17, diperoleh dari jumlah angka sitasi keseluruhan (citation) dibagi citation years; angka sitasi per artikel (cites/paper) sebesar 18.41, diperoleh dari citation dibagi papers; angka sitasi per penulis (cites/author) sebesar 2841.98, diperoleh dari citation dibagi author; untuk angka penulis per artikel (author/paper) sebesar 2.25.

\begin{tabular}{|lr} 
Publication years: & 2002-2020 \\
Citation years: & 18 (2002-2020) \\
Papers: & 272 \\
Citations: & 5007 \\
Cites/year: & 278.17 \\
Cites/paper: & 18.41 \\
Cites/author: & 2841.98 \\
Papers/author: & 159.55 \\
Authors/paper: & 2.25 \\
h-index: & 35 \\
g-index: & 65 \\
hI,norm: & 25 \\
hI,annual: & 1.39 \\
*Count: & 27 \\
& \\
Results &
\end{tabular}

Gambar 2. Analisis nilai publik berdasarkan aplikasi PoP Sumber: Aplikasi PoP (2020)

Untuk menghitung $h$-index yaitu jumlah dari publikasi dan jumlah dari kutipan per-publikasi. g-index dideskripsikan dari akumulasi artikel yang dikutip dari jumlah yang berpengaruh terhadap artikel lain. Perhitungan $g$-index didapat dari keseluruhan jumlah rata-rata yang dikutip, kemudian diurutkan sampai angka $g$. Bobot kutipan yang diterima oleh dokumen kemudian dianalisis dalam perhitungan g-index, untuk peneliti/ilmuwan g-index tertentu tidak dibatasi oleh jumlah total publikasi (Aulianto, Yusup, \& Setianti, 2019). Pada Gambar 2 diperoleh untuk h-index; g-index; hI,norm; hI,annual sebesar 35; 65; 25; 1.39.

\subsection{Perkembangan Publikasi Nilai Publik Berdasarkan Tahun}

Gambar 3 menunjukan grafik pertumbuhan publikasi terhadap kajian nilai publik dari tahun ke tahun selama kurun waktu 20 tahun, mulai dari tahun 2001 - 2020 yang mengalami 
peningkatan yang signifikan. Topik penelitian nilai publik melandai di tahun $2002-2006$, di tahun 2007 - sekarang memiliki perkembangan yang signifikan. Hal ini menunjukkan bahwa penelitian nilai publik mulai banyak dilakukan, sehingga berpeluang untuk meneliti topik ini di masa yang akan datang.

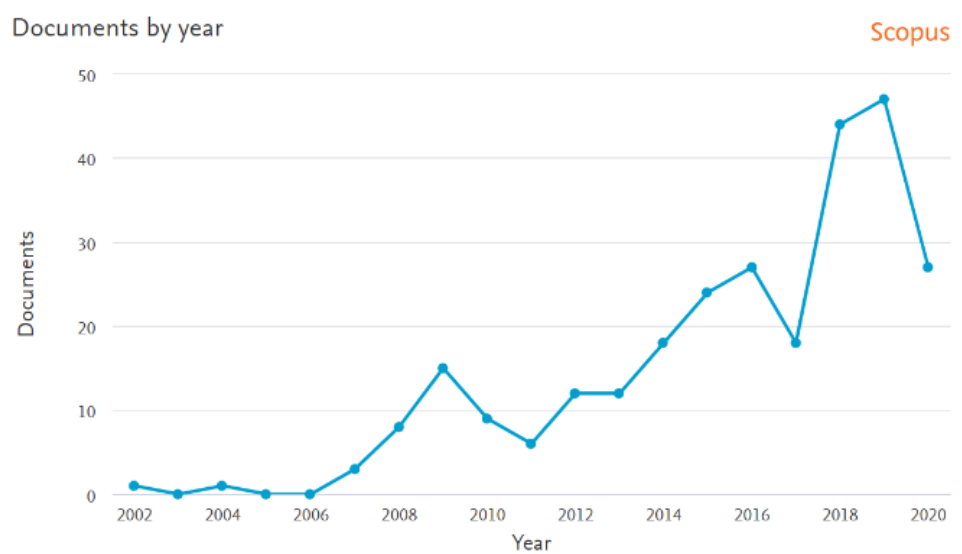

Gambar 3. Perkembangan publikasi nilai publik berdasarkan tahun (Scopus, 2020)

\subsection{Nama Jurnal yang Memuat Publikasi tentang Nilai Publik}

Dari hasil penelusuran di Scopus diketahui nama jurnal yang memuat publikasi penelitian dengan topik nilai publik yang dijelaskan pada Gambar 4 dan Tabel 1.

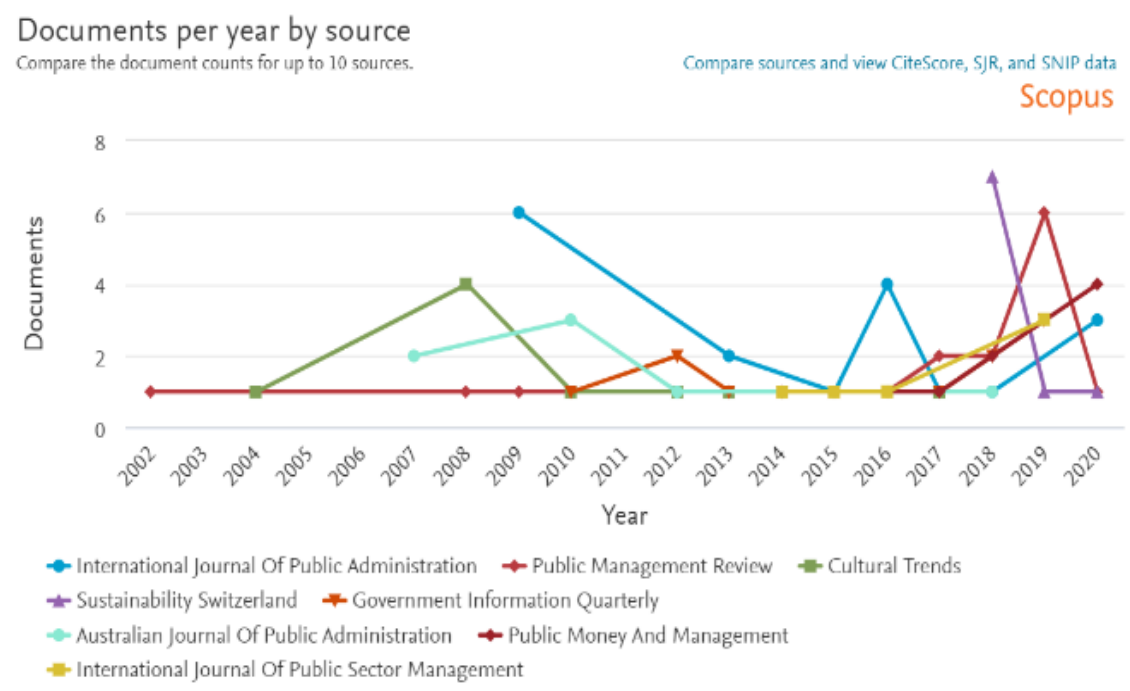

Gambar 4. Nama jurnal yang memuat publikasi tentang nilai publik (Scopus, 2020)

Dari Gambar 4 dan Tabel 1 menunjukkan bahwa terdapat 8 jurnal terbanyak yang mempublikasikan artikel dengan topik penelitian nilai publik dalam kurun waktu dari tahun 2001 - 2020. International Journal of Public Administration merupakan jurnal yang paling banyak mempublikasikan artikel dengan topik penelitian nilai publik sebanyak 18 artikel. Sedangkan International Journal of Public Sector Management mempublikasikan sebanyak 6 artikel.

Tabel 1. Jurnal tentang Nilai Publik

\begin{tabular}{|l|c|}
\hline \multicolumn{1}{|c|}{ Nama Jurnal } & Jumlah \\
\hline International Journal Of Public Administration & 18 \\
\hline Public Management Review & 17 \\
\hline Government Information Quarterly & 11 \\
\hline Cultural Trends & 9 \\
\hline
\end{tabular}




\begin{tabular}{|l|l|}
\hline Sustainability Switzerland & 9 \\
\hline Australian Journal Of Public Administration & 8 \\
\hline Public Money And Management & 8 \\
\hline International Journal Of Public Sector Management & 6 \\
\hline \multicolumn{2}{|c|}{ Sumber: Scopus (2020) }
\end{tabular}

Sumber: Scopus (2020)

\subsection{Jumlah Sitasi Penulis yang Memuat Publikasi Nilai Publik}

Banyaknya sitasi penulis yang memuat publikasi dengan topik nilai publik dapat dilihat pada Tabel 2. Analisis yang dihasilkan oleh Tabel 2 diperoleh dari penelusuran menggunakan aplikasi Publish or Perish (PoP). Dari hasil analisis diambil jumlah sitasi dari penulis yang berjumlah lebih dari 100 sitasi. Artikel karya O'Flynn (2007) dengan judul "From new public management to public value: Paradigmatic change and managerial implications" merupakan artikel yang jumlah sitasinya paling banyak yaitu sebanyak 368 sitasi. Judul artikel dengan jumlah sitasi sebanyak 189 sitasi yaitu "Co-Production and the Co-Creation of Value in Public Services: A suitable case for treatment?" (Osborne, Radnor, and Strokosch 2016).

Jumlah sitasi dari penulis Alford \& Hughes (2008), Grimsley \& Meehan (2007), Alford \& O'Flynn (2009), Moore \& Hartley (2008), Cordella \& Bonina (2012) yaitu sebanyak 178, 174, 173, 171 dan 170 sitasi. Selanjutnya jumlah sitasi dari penulis Crosby \& Bryson (2010) dan Meynhardt (2009) yaitu sebanyak 162 sitasi. Artikel dari penulis Rhodes \& Wanna (2007), Harrison et al. (2012), Bovaird \& Loeffler (2012) dan Alford (2014) sebanyak 158, 152, 149 dan 104 sitasi.

Tabel 2. Sitasi Penulis tentang Nilai Publik

\begin{tabular}{|l|l|c|}
\hline \multicolumn{1}{|c|}{ Penulis } & \multicolumn{1}{|c|}{ Judul } & Sitasi \\
\hline J. O'Flynn & $\begin{array}{l}\text { From new public management to public value: } \\
\text { Paradigmatic change and managerial implications }\end{array}$ & 368 \\
\hline $\begin{array}{l}\text { S.P. Osborne, Z. Radnor, K. } \\
\text { Strokosch }\end{array}$ & $\begin{array}{l}\text { Co-Production and the Co-Creation of Value in Public } \\
\text { Services: A suitable case for treatment? }\end{array}$ & 189 \\
\hline J. Alford, O. Hughes & $\begin{array}{l}\text { Public value pragmatism as the next phase of public } \\
\text { management }\end{array}$ & 178 \\
\hline M. Grimsley, A. Meehan & $\begin{array}{l}\text { e-Government information systems: Evaluation-led } \\
\text { design for public value and client trust }\end{array}$ & 174 \\
\hline J. Alford, J. O'Flynn & $\begin{array}{l}\text { Making sense of public value: Concepts, critiques and } \\
\text { emergent meanings }\end{array}$ & 173 \\
\hline M. Moore, J. Hartley & Innovations in governance & 171 \\
\hline A. Cordella, C.M. Bonina & $\begin{array}{l}\text { A public value perspective for ICT enabled public } \\
\text { sector reforms: A theoretical reflection }\end{array}$ & 170 \\
\hline B.C. Crosby, J.M. Bryson & $\begin{array}{l}\text { Integrative leadership and the creation and maintenance } \\
\text { of cross-sector collaborations }\end{array}$ & 162 \\
\hline T. Meynhardt & Public value inside: What is public value creation? & 162 \\
\hline R.A.W. Rhodes, J. Wanna & $\begin{array}{l}\text { The limits to public value, or rescuing responsible } \\
\text { government from the platonic guardians }\end{array}$ & 158 \\
\hline $\begin{array}{l}\text { T.M. Harrison, S. Guerrero, } \\
\text { G.B. Burke, M. Cook, A. } \\
\text { Cresswell, N. Helbig, J. }\end{array}$ & $\begin{array}{l}\text { Open government and e-government: Democratic } \\
\text { challenges from a public value perspective }\end{array}$ & 152 \\
\hline $\begin{array}{l}\text { T. Bovaird, E. Loeffler } \\
\text { J. Alford }\end{array}$ & $\begin{array}{l}\text { From Engagement to Co-production: The Contribution } \\
\text { of Users and Communities to Outcomes and Public } \\
\text { Value Multiple Facets of Co-Production: Building on the } \\
\text { work of Elinor Ostrom }\end{array}$ & 104 \\
\hline
\end{tabular}

Sumber: Aplikasi PoP (2020) 


\subsection{Jumlah Publikasi Berdasarkan Subjek yang Memuat Publikasi Nilai Publik}

Gambar 5 menunjukkan jumlah publikasi berdasarkan subjek yang terkait dengan nilai publik. Subjek dibidang Social Sciences paling banyak membahas tentang nilai publik dimana presentasenya sebesar 38,8 \% dengan jumlah artikel sebanyak 185 artikel. Sedangkan subjek dibidang Business, Management, and Accounting sebanyak 103 artikel dengan presentase 21,6\%.

Documents by subject area $\quad$ Scopus

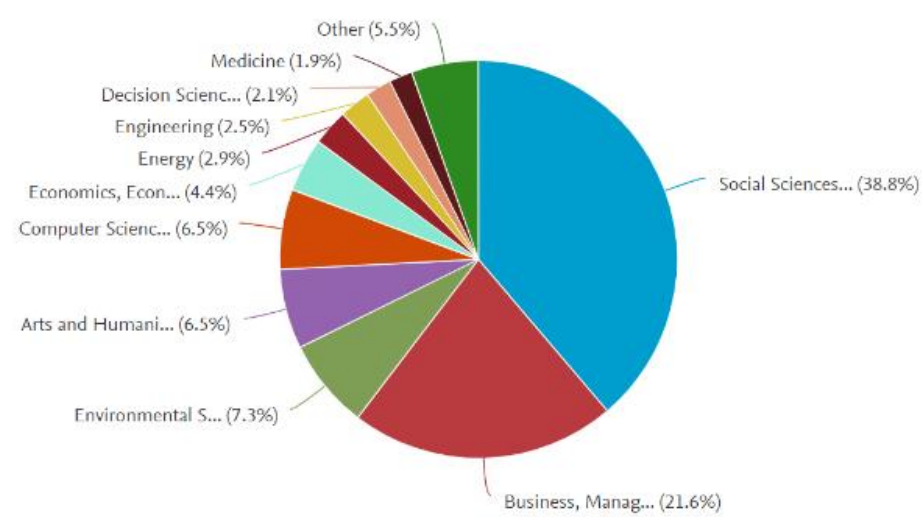

Gambar 5. Artikel berdasarkan subjek yang memuat publikasi tentang nilai publik (Scopus, 2020)

\subsection{Negara yang Memuat Publikasi Nilai Publik}

Analisis lebih lanjut, mendata negara yang terlibat dalam penelitian dengan topik nilai publik dalam Scopus. United Kingdom (65) menjadi negara dengan riset terbesar yang ada dalam basis data Scopus. Kemudian United States (47), Australia (39), Netherlands (19), South Korea (15), Germany (14), Denmark (13), Italy (12), Switzerland (12) dan Spanyol (11). Pada Gambar 6 terlihat bahwa negara Indonesia belum melakukan penelitian terkait topik penelitian tersebut.

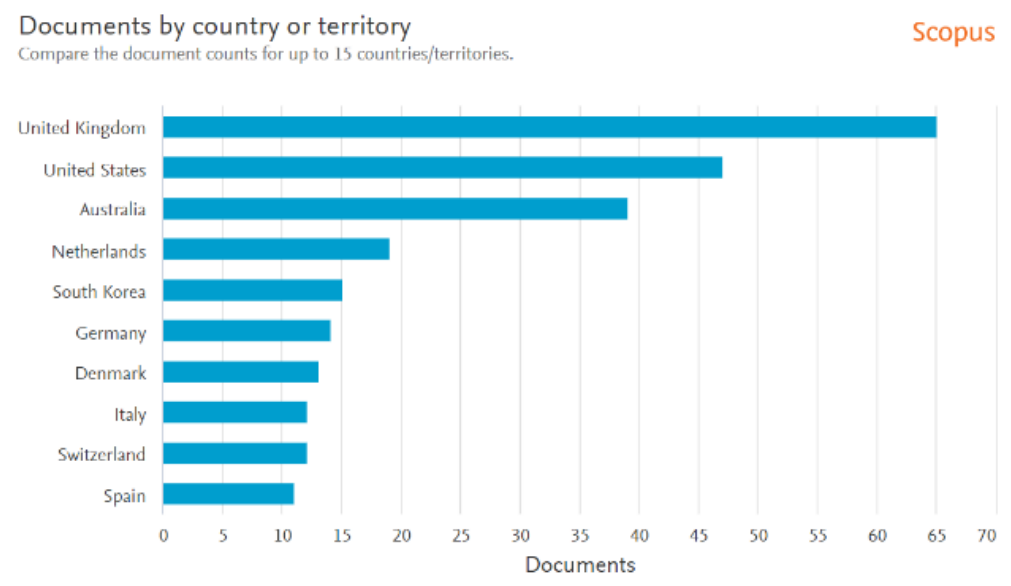

Gambar 6. Negara yang memuat publikasi tentang nilai publik (Scopus, 2020)

\subsection{Peta Visualisasi Network yang Memuat Publikasi Nilai Publik}

Hasil penelusuran publikasi ilmiah terkait topik penelitian nilai publik pada Scopus diperoleh sebanyak 272 dokumen yang kemudian dieksport kedalam format *.RIS, diinput serta dianalisis dengan menggunakan aplikasi VOSviewer sehingga diperoleh hasil visualisasi network dan density peta pertumbuhan publikasi yang ditunjukkan pada Gambar 7 dan Gambar 8 . 


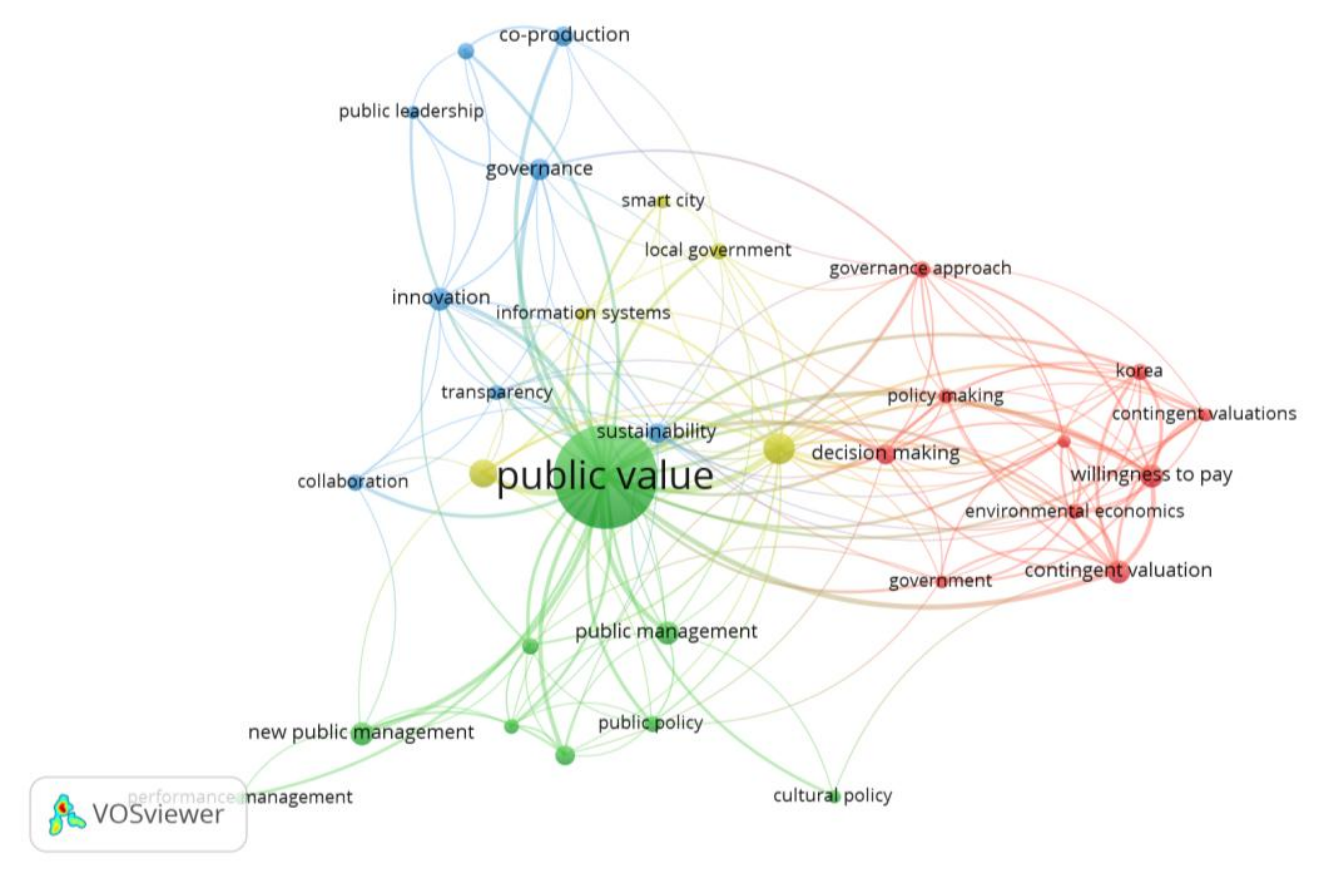

Gambar 7. Peta visualisasi network publikasi tentang nilai publik

Menurut Tupan \& Rachmawati (2018), metode visualisasi dari salah satu bidang ilmu yang dilakukan dengan menciptakan peta landscape yang dapat menggambarkan topik dari ilmu pengetahuan. Network Visualization digunakan untuk melihat jejaring antar-item yang divisualkan. Hasil visualisasi network pada Gambar 6 terbagi dalam 4 kluster. Kluster 1 (warna merah) terdiri dari 10 subjek yaitu contingent valuation, contingent valuations, decision making, environmental economics, governance approach, government, korea, policy making, south korea dan willingness to pay. Kluster 2 (warna hijau) terdiri dari 9 subjek yaitu cultural policy, new public management, performance management, public administration, public management, public policy, public sector, public service dan public value. Kluster 3 (warna biru) terdiri dari 8 subjek yaitu co-creation, co-production, collaboration, governance, innovation, public leadership, sustainability dan transparency. Terakhir kluster 4 terdiri dari 5 subjek yaitu $e$ government, information systems, local government, public values dan smart city.

\subsection{Peta Visualisasi Density yang Memuat Publikasi Nilai Publik}

Peta visualisasi density digunakan untuk melihat kedalaman dari publikasi. Pada Gambar 8 warna paling terang menunjukkan bahwa topik tersebut banyak digunakan dalam judul penelitian terkait nilai publik. Sedangkan yang berwarna tipis, berarti topik tersebut masih berpeluang besar untuk diteliti. 


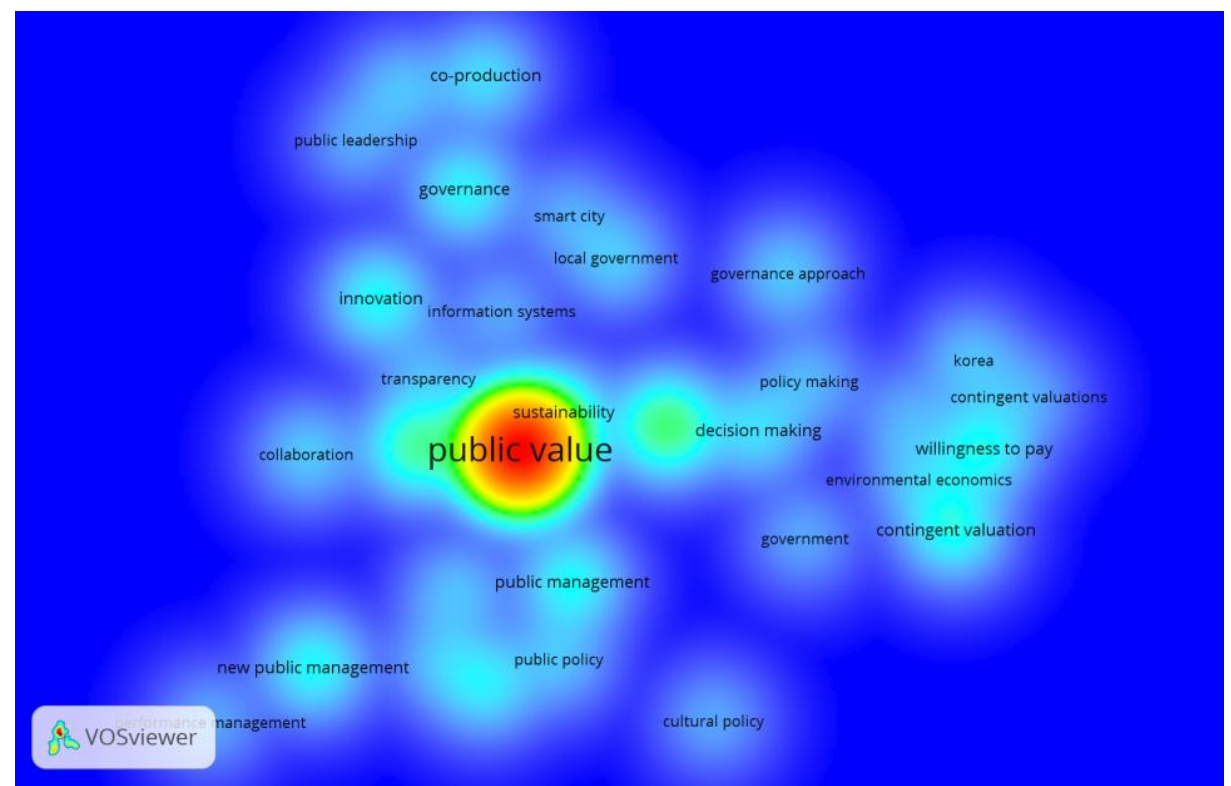

Gambar 8. Peta Visualisasi Density Publikasi tentang Nilai Publik

Berdasarkan peta density terlihat bahwa penelitian dengan topik nilai publik dengan subjek performance management dan cultural policy masih sedikit, dan di Indonesia belum ada yang melakukan penelitian terkait topik nilai publik sehingga masih terbuka kesempatan untuk meneliti topik ini dimasa datang.

\section{KESIMPULAN}

Dari hasil pembahasan di atas dapat disimpulkan bahwa perkembangan publikasi ilmiah dengan topik penelitian nilai publik selama kurun waktu 20 tahun dari tahun $2001-2020$ sebanyak 272 publikasi serta mengalami kenaikan yang signifikan. Walaupun topik nilai publik ditahun 2001 belum ada peneliti yang melakukan, tahun 2002 penelitian dengan topik nilai publik baru dilakukan. Publikasi dengan topik penelitian nilai publik tertinggi di tahun 2019 sebanyak 47 publikasi, kemudian yang terendah terjadi pada tahun 2002 dan 2004 yaitu sebanyak 1 publikasi. Selain itu, penelitian dengan topik penelitian nilai publik berdasarkan basis data Scopus belum ada di Indonesia. Hal ini menjadikan peluang yang sangat besar bagi peneliti di Indonesia untuk terus berkarya menerbitkan publikasi di skala Internasional. Penelitian kedepan disarankan untuk menganalisis tidak hanya dari basis data Scopus saja tetapi bisa dikombinasikan dengan basis data WoS dan Google Scholar serta penambahan kata kunci agar hasil yang diperoleh bisa lebih banyak dan komprehensif.

\section{DAFTAR PUSTAKA}

Alford, J.. 2014. The Multiple Facets of Co-Production: Building on the Work of Elinor Ostrom. Public Management Review, 16(3): 299-316. https://doi.org/10.1080/14719037.2013.806578.

Alford, J., \& Hughes, O. 2008. Public Value Pragmatism as the next Phase of Public Management. American Review of Public Administration, 38(2): 130-48. https://doi.org/10.1177/0275074008314203.

Alford, J. \& O’Flynn, J. 2009. Making Sense of Public Value: Concepts, Critiques and Emergent Meanings. International Journal of Public Administration, 32(3-4): 171-91. https://doi.org/10.1080/01900690902732731.

Aulianto, D.R., Yusup, P.M., \& Setianti, Y. 2019. Pemanfaatan Aplikasi ‘ Publish Or Perish' Sebagai 
Alat Analisis Sitasi Pada Jurnal Kajian Komunikasi Universitas Padjadjaran. In Seminar Nasional MACOM III "Communication and Information Beyound Boundaries, 873-80. Universitas Padjajaran.

Benington, J. \& Moore, M.H. 2011. Public Value in Complex and Changing Times. Public Value. Macmillan Education UK. https://doi.org/10.1007/978-0-230-36431-8_1.

Bensman, S.J. 2011. Anne-Wil Harzing: The Publish or Perish Book: Your Guide to Effective and Responsible Citation Analysis. Scientometrics, 88(1): 339-42. https://doi.org/10.1007/s11192011-0388-8.

Bovaird, T. \& Loeffler, E. 2012. From Engagement to Co-Production: The Contribution of Users and Communities to Outcomes and Public Value. Voluntas, 23(4): 1119-38. https://doi.org/10.1007/s11266-012-9309-6.

Bozeman, B.. 2007. Public Values and Public Interest: Counterbalancing Economic Individualism. Public Values and Public Interest: Counterbalancing Economic Individualism, 44: 1-214. https://doi.org/10.1057/ap.2009.14.

Bromell, D. 2017. Creating Public Value. The Art and Craft of Policy Advising. Springer I. https://doi.org/10.1007/978-3-319-52494-8.

Bryson, J.M., Crosby, B.C., \& Bloomberg, L. 2014. Public Value Governance: Moving beyond Traditional Public Administration and the New Public Management. Public Administration Review 74 (4): 445-56. https://doi.org/10.1111/puar.12238.

Cordella, A. \& Bonina, C.M. 2012. A Public Value Perspective for ICT Enabled Public Sector Reforms: A Theoretical Reflection. Government Information Quarterly, 29(4): 512-20. https://doi.org/10.1016/j.giq.2012.03.004.

Crosby, Barbara C., \& Bryson, J.M. 2010. Integrative Leadership and the Creation and Maintenance of Cross-Sector Collaborations. Leadership Quarterly, 21(2): 211-30. https://doi.org/10.1016/j.leaqua.2010.01.003.

Eck, Nees Jan Van, \& Waltman, L. 2009. VOSviewer: A Computer Program for Bibliometric Mapping." 12th International Conference on Scientometrics and Informetrics, ISSI 2009, 88697.

Garza-Reyes, J.A. 2015. Lean and Green-a Systematic Review of the State of the Art Literature. Journal of Cleaner Production, 102: 18-29. https://doi.org/10.1016/j.jclepro.2015.04.064.

Grimsley, M. \& Meehan, A. 2007. E-Government Information Systems: Evaluation-Led Design for Public Value and Client Trust.European Journal of Information Systems, 16(2): 134-48. https://doi.org/10.1057/palgrave.ejis.3000674.

Harmon, M.M. 2011. In Defense of Politics in Public Administration: A Value Pluralist Perspective." Administrative Theory \& Praxis 33 (1): 143-48. https://doi.org/10.2753/atp1084-1806330111.

Harrison, T.M., Guerrero, S., Burke, G.B., Cook, M., Cresswell, A., Helbig, N., Hrdinova, J., \& Pardo, T. 2012. Open Government and E-Government: Democratic Challenges from a Public Value Perspective. Information Polity, 17(2): 83-97. https://doi.org/10.3233/IP-2012-0269.

Jørgensen, T.B. \& Bozeman, H. 2007. Public Values. Administration \& Society, 39(3): 354-81. https://doi.org/10.1177/0095399707300703. 
Jørgensen, T.B. \& Rutgers, M.R. 2015. Public Values: Core or Confusion? Introduction to the Centrality and Puzzlement of Public Values Research. American Review of Public Administration, 45(1): 3-12. https://doi.org/10.1177/0275074014545781.

Meynhardt, T. 2009. Public Value inside: What Is Public Value Creation? International Journal of Public Administration, 32(3-4): 192-219. https://doi.org/10.1080/01900690902732632.

Moore, M. 1995. Creating Public Value: Strategic Management in Government. Cambridge, MA: Harvard University Press. Edited by Harvard University Press.

Moore, M. \& Hartley, J. 2008. Innovations in Governance. Public Management Review, 10(1): 3-20. https://doi.org/10.1080/14719030701763161.

Nabatchi, T. 2012. Putting the 'Public' Back in Public Values Research: Designing Participation to Identify and Respond to Values. Public Administration Review, 72(5): 699-708. https://doi.org/10.1111/j.1540-6210.2012.02544.x.

Naukkarinen, O. \& Bragge, J. 2016. Aesthetics in the Age of Digital Humanities." Journal of Aesthetics and Culture 8 (January). https://doi.org/10.3402/jac.v8.30072.

O’Flynn, J. 2007. From New Public Management to Public Value: Paradigmatic Change and Managerial Implications. Australian Journal of Public Administration, 66(3): 353-66. https://doi.org/10.1111/j.1467-8500.2007.00545.x.

Osborne, S.P., Radnor, Z., \& Strokosch, K. 2016. Co-Production and the Co-Creation of Value in Public Services: A Suitable Case for Treatment? Public Management Review, 18(5): 639-53. https://doi.org/10.1080/14719037.2015.1111927.

Rhodes, R.A.W. \& Wanna, J. 2007. The Limits to Public Value, or Rescuing Responsible Government from the Platonic Guardians. Australian Journal of Public Administration, 66(4): 406-21. https://doi.org/10.1111/j.1467-8500.2007.00553.x.

Setyaningsih, I. 2019. Perkembangan Topik Halal dalam Penelitian (Sebuah Tinjauan Literatur). In 1st Conference on Industrial Engineering and Halal Industries (CIEHIS), 55-60.

Spicer, M.W. 2009. Value Conflict and Legal Reasoning in Public Administration. Administrative Theory \& Praxis, 31(4): 537-55. https://doi.org/10.2753/atp1084-1806310405.

Tranfield, D., Denyer, D., Smart, P., Goodhue, D.L., \& Thompson, R.L. 2003. Towards a Methodology for Developing Evidence-Informed Management Knowledge by Means of Systematic Review. British Journal of Management, 14(2): 207-22. https://doi.org/10.2307/249689.

Tupan, T., \& Rachmawati, R. 2018. Analisis Bibliometrik Ilmu dan Teknologi Pangan: Publikasi Ilmiah di Negara-Negara ASEAN. Khizanah Al-Hikmah: Jurnal Ilmu Perpustakaan, Informasi, dan Kearsipan, 6(1): 26-40. https://doi.org/10.24252/kah.v6i1a4.

Wal, Z.V.D \& Hout, E.T.J.V. 2009. Is Public Value Pluralism Paramount? The Intrinsic Multiplicity and Hybridity of Public Values. International Journal of Public Administration, 32(3-4): 22031. https://doi.org/10.1080/01900690902732681.

Williams, I. \& Shearer, H. 2011. Appraising Public Value: Past, Present and Futures. Public Administration, 89 (4): 1367-84. https://doi.org/10.1111/j.1467-9299.2011.01942.x. 